\title{
Constraints Faced by Farmers in Adoption of Recommended Grain Storage Practices
}

\author{
S. P. Gaikwad ${ }^{1}$, M. N. Panpatte ${ }^{2}$, P. S. Kanase ${ }^{3}$ and R. B. Kalamkar ${ }^{1 *}$ \\ ${ }^{1}$ Department of Extension Education, College of Agriculture, Baramati, Pune, India \\ ${ }^{2}$ Department of Extension Education, College of Agriculture, Umarkhed, Yavatmal, India \\ ${ }^{3}$ Department of Extension Education, RCSMC College of ABM, Sangali, India \\ *Corresponding author
}

Keywords

Constraints, Grain storage structure, Adoption

Article Info

Accepted:

26 May 2020

Available Online:

10 June 2020

\begin{abstract}
A B S T R A C T
Present study was conducted in Basmat taluka of Hingoli district. Ten villages having highest area under food grain crops were selected for the study. From each village, 12 respondents were selected randomly, who stored food grains to their home and godowns. Thus a sample of 120 respondents was selected for the study. The data was collected through personal interview method with the help of structured schedule. The data was statistically analysed with the help of frequency and percentage. Through this study it was revealed that most of respondents (60.84 per cent) had medium level of adoption about recommended grain storage practices, while 22.50 per cent and 16.66 per cent had low and high level of adoption about recommended grain storage practices respectively. Regarding constraint lack of proper training (90.83 per cent), non-availability of separate space for storage ( 80.83 per cent) and due to poor economical condition grain is sold ( 70.83 per cent) were the major constraints encountered by the respondents in adoption of recommended grain storage practices.
\end{abstract}

\section{Introduction}

In India, out of total food grains production about 70 per cent is retained and stored by farmers for household consumption, for use of seed, feed for cattle and payment of labour in kind. Only 30 per cent food grains go to market. Some times farmers can afford to store grains for longer period so as to get higher price.

Grains during storage are attacked by insects, rodents, birds and microorganism. Apart from this, grains are contaminated by the excreta of insects, hair, pellets of rats, leading to consumer hazard. Various store grain pests are grain moth, grain weevil, rust red flour beetle, rice moth, etc., they are responsible for deterioration in food grains.

According to Indian Grain Storage Management \& Research Institute (Igmri), Hapur(U.P), GOI in India, annual storage losses have been estimated14 -million tones worth of Rs. 7,000 crore in which insects alone account for nearly Rs. 1,300 
cores. Post-harvest losses account for about $10 \%$ of total food grains due to unscientific storage, lack of technical knowledge of farmers to protect $\&$ preserve food grains with adequate handling and storage practices.

Research in post harvest technology was undertaken and various improved storage structures and practices were developed to reduce grain loss and were recommended for use. It is expected that farmers must use of preventive and control measures and improved storage structures which minimize the grain losses during storage. In order to study the constraints faced by farmers in adoption of grain storage practices, the investigation was undertaken with the following objectives include to study the extend of adoption of recommended grain storage practices by the respondents. And also to identify the constraints encountered by the respondents in adoption of recommended grain storage practices.

\section{Materials and Methods}

Present study was conducted in Basmat taluka of Hingoli district, because this taluka occupies major area under food grains. Ten villages having highest area under food grain crops were selected for the study. From each village, 12 respondents were selected randomly, who stored food grains to their home and godowns. Thus a sample of 120 respondents was drawn for the study. The data was collected through personal interview method with the help of structured schedule. The data was statistically analysed with the help of frequency and percentage.

The adoption of respondent in respect of recommended grain storage practices was studied by computing adoption score. two score was assigned for full adoption, one score for partial adoption and zero score for no adoption. On the basis of total score obtained the adoption index was calculated for each farmer.

In this way the scoring of each respondent was worked out and they were classified as per their adoption index on the basis of mean and standard deviation.

In the present study, constraints have been operationally defined as the problems encountered or perceived by the respondents with regard to adoption of recommended grain storage practices. There were 10 items under constraints, which are encountered by farmers. The number and percentage of each constraints were worked out to measure the constraints encountered by the respondents.

\section{Results and Discussion}

\section{Practice wise adoption of recommended grain storage practices by the respondents}

The data in Table 1 revealed that all the respondents (100 per cent) dried food grains in sunlight before storage, but non of the respondents were using artificial drying method for drying grains with the help of dryer. Majority of the respondents (93.33 per cent) used proper gunny bags for storage, similarly 93.33 per cent of the respondents adopted measures to protect grains from birds, insects and rats; followed by 86.67 per cent of the respondents who did not allow stagnant water around godown, similar percentage i.e. 86.67 per cent of the respondents were using the practice of removal residual grains from bags, while 83.33 per cent and 80.00 per cent of the respondents adopted practice of sundrying of wet gunny bags and drying of grains in shadow which are used for seed purposes respectively. It was also observed that the most of the respondents (70.00 per cent) sealed all cracks of godowns as well as maintain side space from wall while stacking the bags. Also most of the respondents (66.67 
per cent) were netting windows for protection from birds in godowns, followed by 63.33 per cent of the respondents use to remove residual grains from the godowns. Also near about half of the respondents (58.33 per cent) did not maintained elevated status of godowns.

Regarding partial adoption of recommended grain storage practices, most of the respondents (70.00 per cent) used chemical control measures for control of store grain pests, followed by 46.67 per cent of the respondents used chemicals for control of rodents, while 40.00 per cent and 36.67 per cent of the respondents used chemicals for control of pests of grains stored for seed purpose and used fumigants, respectively.

It is further apparent from relevant data that majority of the respondents (96.67 per cent) not maintain suitable distance between floor and door of godown, followed by 93.33 per cent of the respondents were not using metal sheet for rat proofing, while 80.00 per cent of the respondents did not maintain suitable atmospheric condition in godowns. And also most of the respondents (69.17 per cent) not maintain low humidity in godowns, followed by 65.83 per cent of the respondents did not stack bag in such way that it facilitate better supervision in the godowns. It was further reported that, significant percentage of the respondents (56.67 per cent) not adopted recommended grain storage structures, followed by half of the respondents (50.00 per cent) adopted the practice of stacking of bags above 3 feet from floor.

\section{Level of adoption}

The data in table 2 portrayed that the most of respondents (60.84 per cent) had medium level of adoption about recommended grain storage practices, while 22.50 per cent and 16.66 per cent had low and high level of adoption about recommended grain storage practices respectively. Similar finding were obtained in the studies of Borkar and Rashekar (1999), Gamini Sahu et.al.(2015).

\section{Constraints encountered by the respondents in the adoption of recommended grain storage practices}

It is perused from the table 3, that an overwhelming majority of respondents stated that lack of proper training ( 90.83 per cent), non-availability of separate space for storage (80.83 per cent) and due to poor economical condition grain is sold (70.83 per cent) were the major constraints encountered by the respondents in adoption of recommended grain storage practices. In addition, majority of the respondents reported the constraints namely, lack of guidance about improved storage structure (63.33 per cent), lack of information about chemical control of stored grain pests (42.50 per cent), followed by 41.66 per cent of the respondents faced lack of finance for construction of improved storage structures and 35 per cent of the respondents expressed lack of knowledge of stored grain pests. As much as 28.33 per cent, 25.00 per cent and 24.16 per cent of the respondents expressed constraints of lack of knowledge about fumigants, small quantity of grains available for storage and costliness of erection of improved storage structure respectively in adoption of recommended grain storage practices. These findings are in line of findings of Nikhade and Nimje (1998), Khule et.al. (2011), Mane (2015), Gamini Sahu et.al. (2015).

In conclusion, the findings of the present investigation revealed that majority of the respondents possessed medium level of adoption about recommended grain storage practices. Constraints mentioned by respondent are lack of proper training, guidance about improved storage structure, chemical control of stored grain pests etc. Hence the farmers need to be equipped with 
still higher knowledge about recommended and improved grain storage practices, through organization of the trainings and through radio, television programmes and also by conducting demonstrations, seminars and field days to educate farmers in recommended grain storage practices.

Table.1 Distribution of the respondents according to practice wise adoption of grain storage

\begin{tabular}{|c|c|c|c|c|}
\hline $\begin{array}{l}\text { Sr. } \\
\text { No. }\end{array}$ & Practices & $\begin{array}{l}\text { Complete } \\
\text { adoption }\end{array}$ & $\begin{array}{l}\text { Partial } \\
\text { adoption }\end{array}$ & $\begin{array}{l}\text { No } \\
\text { Adoption }\end{array}$ \\
\hline \multicolumn{5}{|c|}{ Methods of drying } \\
\hline 1 & Drying of food grains before storage & $\begin{array}{c}120 \\
(100.00)\end{array}$ & $\begin{array}{c}0 \\
(0.00)\end{array}$ & $\begin{array}{c}0 \\
(0.00)\end{array}$ \\
\hline 2 & Drying of grains in sunlight & $\begin{array}{c}120 \\
(100.00)\end{array}$ & $\begin{array}{c}0 \\
(0.00)\end{array}$ & $\begin{array}{c}0 \\
(0.00)\end{array}$ \\
\hline 3 & Drying of grains with the help of dryers & $\begin{array}{c}0 \\
(0.00)\end{array}$ & $\begin{array}{c}0 \\
(0.00)\end{array}$ & $\begin{array}{c}120 \\
(100.00)\end{array}$ \\
\hline \multicolumn{5}{|c|}{ Precautionary measures for taking care of godowns } \\
\hline 4 & Maintain cool atmosphere in gowdowns & $\begin{array}{c}24 \\
(20.00)\end{array}$ & $\begin{array}{c}0 \\
(0.00)\end{array}$ & $\begin{array}{c}96 \\
(80.00)\end{array}$ \\
\hline 5 & $\begin{array}{l}\text { Removing of residual grains from gowdowns and } \\
\text { clean it }\end{array}$ & $\begin{array}{c}76 \\
(63.33)\end{array}$ & $\begin{array}{c}0 \\
(0.00)\end{array}$ & $\begin{array}{c}44 \\
(36.67)\end{array}$ \\
\hline 6 & To seal all cracks of godowns & $\begin{array}{c}84 \\
(70.00)\end{array}$ & $\begin{array}{c}0 \\
(0.00)\end{array}$ & $\begin{array}{c}36 \\
(30.00)\end{array}$ \\
\hline 7 & Netting the windows for protections from birds & $\begin{array}{c}80 \\
(66.67)\end{array}$ & $\begin{array}{c}0 \\
(0.00)\end{array}$ & $\begin{array}{c}40 \\
(33.33)\end{array}$ \\
\hline 8 & Proofing of godowns with $25 \mathrm{~cm}$ metal sheet & $\begin{array}{c}8 \\
(6.67)\end{array}$ & $\begin{array}{c}0 \\
(0.00)\end{array}$ & $\begin{array}{c}112 \\
(93.33)\end{array}$ \\
\hline 9 & Not allowing stagnant water around godown & $\begin{array}{c}104 \\
(86.67)\end{array}$ & $\begin{array}{c}0 \\
(0.00)\end{array}$ & $\begin{array}{c}16 \\
(13.33)\end{array}$ \\
\hline \multicolumn{5}{|c|}{ Precautionary measures during reuse of old gunny bags } \\
\hline 10 & Use of proper gunny bags only & $\begin{array}{c}112 \\
(93.33)\end{array}$ & $\begin{array}{c}0 \\
(0.00)\end{array}$ & $\begin{array}{c}8 \\
(6.67)\end{array}$ \\
\hline 11 & Removal of residual grains from bags & $\begin{array}{c}104 \\
(86.67)\end{array}$ & $\begin{array}{c}0 \\
(0.00)\end{array}$ & $\begin{array}{c}16 \\
(13.33)\end{array}$ \\
\hline 12 & Sundrying of wet gunny bags & $\begin{array}{c}100 \\
(83.33)\end{array}$ & $\begin{array}{c}0 \\
(0.00)\end{array}$ & $\begin{array}{c}20 \\
(16.67)\end{array}$ \\
\hline 13 & $\begin{array}{l}\text { Use of recommended scientific grain storage } \\
\text { structure }\end{array}$ & $\begin{array}{c}52 \\
(43.33)\end{array}$ & $\begin{array}{c}0 \\
(0.00)\end{array}$ & $\begin{array}{c}68 \\
(56.67)\end{array}$ \\
\hline 14 & $\begin{array}{l}\text { Chemical control measures for control of stored } \\
\text { grain pests. }\end{array}$ & $\begin{array}{c}0 \\
(0.00)\end{array}$ & $\begin{array}{c}84 \\
(70.00)\end{array}$ & $\begin{array}{c}36 \\
(30.00)\end{array}$ \\
\hline \multicolumn{5}{|c|}{ Care to be taken while stacking bags } \\
\hline 15 & Stacking of bags above 3 feet from floor & $\begin{array}{c}60 \\
(50.00)\end{array}$ & $\begin{array}{c}0 \\
(0.00)\end{array}$ & $\begin{array}{c}60 \\
(50.00)\end{array}$ \\
\hline 16 & Maintain side space from wall & $\begin{array}{c}84 \\
(70.00)\end{array}$ & $\begin{array}{c}0 \\
(0.00)\end{array}$ & $\begin{array}{c}36 \\
(30.00)\end{array}$ \\
\hline
\end{tabular}




\begin{tabular}{|c|c|c|c|c|}
\hline 17 & $\begin{array}{l}\text { Stacking of bags in such way that, which facilitate } \\
\text { better supervision }\end{array}$ & $\begin{array}{c}41 \\
(34.17)\end{array}$ & $\begin{array}{c}0 \\
(0.00)\end{array}$ & $\begin{array}{c}79 \\
(65.873)\end{array}$ \\
\hline 18 & $\begin{array}{l}\text { Chemical control measures for control of pests of } \\
\text { grain stored for seed purpose }\end{array}$ & $\begin{array}{c}0 \\
(0.00)\end{array}$ & $\begin{array}{c}48 \\
(40.00)\end{array}$ & $\begin{array}{c}72 \\
(60.00)\end{array}$ \\
\hline \multicolumn{5}{|c|}{ Precautionary measures to be taken to retain viability of seed } \\
\hline 19 & $\begin{array}{l}\text { Drying of food grains in shadow which are used for } \\
\text { seed purpose }\end{array}$ & $\begin{array}{c}96 \\
(80.00)\end{array}$ & $\begin{array}{c}0 \\
(0.00)\end{array}$ & $\begin{array}{c}24 \\
(20.00)\end{array}$ \\
\hline 20 & Protect grains from birds, insects, fungi, rats & $\begin{array}{c}112 \\
(93.33)\end{array}$ & $\begin{array}{c}0 \\
(0.00)\end{array}$ & $\begin{array}{c}8 \\
(6.67)\end{array}$ \\
\hline 21 & Maintain low humidity in godowns & $\begin{array}{c}37 \\
(30.83)\end{array}$ & $\begin{array}{c}0 \\
(0.00)\end{array}$ & $\begin{array}{c}83 \\
(69.17)\end{array}$ \\
\hline 22 & Use of fumigants & $\begin{array}{c}0 \\
(0.00)\end{array}$ & $\begin{array}{c}44 \\
(36.67)\end{array}$ & $\begin{array}{c}76 \\
63.33)\end{array}$ \\
\hline 23 & Use of chemicals for rat control & $\begin{array}{c}0 \\
(0.00)\end{array}$ & $\begin{array}{c}56 \\
(46.67)\end{array}$ & $\begin{array}{c}64 \\
(53.33)\end{array}$ \\
\hline 24 & $\begin{array}{l}\text { Construction of godowns at higher level from that } \\
\text { of ground level (Eleveted) }\end{array}$ & $\begin{array}{c}70 \\
(58.33)\end{array}$ & $\begin{array}{c}0 \\
(0.00)\end{array}$ & $\begin{array}{c}50 \\
(41.67)\end{array}$ \\
\hline 25 & Distance between floor and door is less than $0.6 \mathrm{~cm}$ & $\begin{array}{c}4 \\
(3.33)\end{array}$ & $\begin{array}{c}0 \\
(0.00)\end{array}$ & $\begin{array}{c}116 \\
(96.67)\end{array}$ \\
\hline
\end{tabular}

Table.2 Distribution of the respondents according to level of adoption of recommended grain storage practices

\begin{tabular}{|c|l|c|c|}
\hline Sr. No. & \multicolumn{1}{|c|}{ Categories } & Frequency & Percentage \\
\hline $\mathbf{1}$ & Low & 27 & 22.50 \\
\hline $\mathbf{2}$ & Medium & 73 & 60.84 \\
\hline $\mathbf{3}$ & High & 20 & 16.66 \\
\hline & Total & $\mathbf{1 2 0}$ & $\mathbf{1 0 0}$ \\
\hline
\end{tabular}

Table.3 Distribution of the respondents according to constraints encountered in adoption of recommended grain storage practices

\begin{tabular}{|c|l|c|c|}
\hline $\begin{array}{c}\text { Sr } \\
\text { No. }\end{array}$ & \multicolumn{1}{|c|}{ Constraints } & Frequency & Percentage \\
\hline $\mathbf{1}$ & Lack of knowledge of stored grain pests & 42 & 35.00 \\
\hline $\mathbf{2}$ & Lack of information about chemical control of stored grain pests & 51 & 42.50 \\
\hline $\mathbf{3}$ & Lack of guidance for use of improved storage structures & 76 & 63.33 \\
\hline $\mathbf{4}$ & Lack of finance for construction of improved storage structures & 50 & 41.66 \\
\hline $\mathbf{5}$ & Lack of proper training & 109 & 90.83 \\
\hline $\mathbf{6}$ & Non-availability of separate place for storage of grains & 97 & 80.83 \\
\hline $\mathbf{7}$ & Lack of knowledge about fumigants & 34 & 28.33 \\
\hline $\mathbf{8}$ & Small quantity of grains available for storage & 30 & 25.00 \\
\hline $\mathbf{9}$ & Costliness of erection of improved storage structures & 29 & 24.16 \\
\hline $\mathbf{1 0}$ & Due to poor economical condition grain is sold & 85 & 70.83 \\
\hline
\end{tabular}




\section{References}

Borkar, M.M. and A. K. Rashekhar (1999). Adoption of grain storage by farm families. Maharashtra J. Extn. Edn., $152-154$

Gamini Sahu, K. K. Shrivastava and B. K. Chaturvedi (2015). Adoption of storage practices of food grains among the farmers of northern hills of Chhattisgarh, India., Plant Archives Vol. 15 No. 2, 2015 pp. 813-815

Khule, R. P., Sasane, G. K. and Jagdale, U. D. (2011). Source of information used and constraints faced by the farmers about adoption of food grain storage practices. Agriculture Update 2011, Vol.6, No.1, pp.119-121.

Mane M. M. (2015). Knowledge and adoption of food grain storage practices by the rural women. M. Sc. (Agri), Thesis, V.N.M.A.U., Parbhani

Nikhade, D.M. and N. R. Nimje (1998). Involvement of rural women in Agriculture. Paper presented in seminar on role of Farm women in Agriculture. M.S.E.E., 7-8 Oct., Akola

\section{How to cite this article:}

Gaikwad, S. P., M. N. Panpatte, P. S. Kanase and Kalamkar, R. B. 2020. Constraints Faced by Farmers in Adoption of Recommended Grain Storage Practices. Int.J.Curr.Microbiol.App.Sci. 9(06): 3418-3423. doi: https://doi.org/10.20546/ijcmas.2020.906.405 